Tarbawi, Volume 5 No. 12020

Syamsul Rizal \& Azhari Fathurrohman, The Use Of Video To Improve The Speaking Skill

\title{
The Use Of Video To Improve The Speaking Skill Of The First Semester Students Of Pgmi Program Of Hamzanwadi Islamic Institute (IAIH) NW AT Pancor
}

\author{
Syamsul Rizal \&Azhari Fathurrohman \\ IAI Hamzanwadi NW Pancor \\ Email; syamsulrizalrensing@gmail.com
}

\begin{abstract}
The teaching of English as a Foreign Language (EFL) speaking is necessary for university students to have basic skills of oral communication. Using teaching media in the teaching of EFL speaking might be beneficial to help students improve their speaking skills. As teaching media, video can offer audio and visual model of target language as complete stimuli. The aim of this research was to investigate the use of video as teaching media to improve the speaking skill of the first semester students of PGMI program of IAIH NW at Pancor. Based on the data of preliminary study, it was found that the students encountered many problems in their speaking class such as; the students had low motivation and reticence to speak, poor grammar and vocabulary, and had some errors in pronunciation.

With regard to the problem, this classroom action research was conducted to solve those problems occurring in the speaking class. This research was a collaborative action research in which a collaborator assisted the researcher to collect the data using speaking scoring rubric, questionnaire and field notes. This research was conducted in two cycles focusing on the improvement of the students' speaking performance and their positive attitude to the implementation of the use of video as teaching media in the speaking class.

After the implementation of the use of video as teaching media in the speaking class for two cycles, it revealed that the use of video could improve the students' speaking performance and give them positive attitude to the implementation activities. The findings showed that the average score of the students' speaking performance could achieve 85.11 from the determined score 75 . In addition, it was also found that $84.13 \%$ of the students had positive attitude to the implementation of the use of video in the speaking class.

The implementation of the use of video as teaching media in speaking class can cover a procedure of three main phases: The first phase is pre-viewing, the second phase is whilst-viewing, and the third phase is post-viewing.

Based on the findings, it is concluded that the use of video as teaching media can be one of the solutions to improve not only the students' speaking skills but also the their' positive attitude in the teaching of speaking. Therefore, English teachers are suggested to use the video as teaching media to teach their students in speaking class and it is also possible to teach other language skills or components.
\end{abstract}

Key Words: video, teaching media, speaking skill. 
Tarbawi, Volume 5 No. 12020

Syamsul Rizal \& Azhari Fathurrohman, The Use Of Video To Improve The Speaking Skill

\section{Introduction}

Responding to English as a language of international communication and lingua franca, people considerably think to learn English, which is used and spoken worldwide for education, business, communication, and others. With regard to the importance of English as a Second or Foreign language (ESL or EFL), the teaching of EFL speaking has been deemed important in the Indonesian context. In general, Richards and Renandya (2002:201) point out that a large number of language learners study English in order to develop proficiency in speaking. Hence, speaking is usually considered as the core skill in a foreign language learning and it is what learners generally want to be able to do (Broady, 2005; Graham, 2007).

To be able to speak English fluently and accurately, however, requires supporting knowledge and other skills of speaking. It also entails a full understanding of what is involved in the speaking skill. Burns and Joyce (1997:2) acknowledges that the mastery of the speaking skills engage a number of complex skills and types of knowledge about how and when to communicate. Similarly, Thornbury (2005:11) adds that to have a sufficient skill of speaking the EFL learners require linguistic knowledge and extra linguistic knowledge. Thus, the significance of understanding familiarity of speaking skills and related skills might favor EFL learners improve their speaking skill.

Regarding some factors that really influence the quality of the speaking skill, Harmer (2001:269) emphasizes that to speak well, speakers should have not only a good comprehension on knowledge of language features, but also the ability to process information and language in context. In line with Harmer, Shumin (2002:204) states that when people learn to speak a foreign language, they require more than knowing its grammatical and semantic rules, and learners need to acquire the knowledge of how native speakers use the language in context. In short, understanding those factors really facilitate EFL learners' awareness of the speaking skill and improve its quality.

A common problem that occurs in a speaking class is that teachers frequently feel it difficult to involve students in the speaking activities. In fact, English teachers should work hard to attract the students to speak a lot in the class. It occurs because many EFL learners have such personality problems, for instance they are not confident, reluctant, and afraid of practicing and using their English. Brown (2001:269) notes one of the major obstacles learners have to overcome in learning to speak is the anxiety generated over the risks of blurting things out that are wrong, stupid, or incomprehensible. Rarastesa (2004:322) contends that the most difficult part of teaching in a speaking class is to make them speak up. Their views of speaking problems were supported by the claim that some EFL learners are reluctant to speak because of many factors such as inadequate vocabulary and control of grammar, lack of fluency, encouragement, and the students' shyness 
(Nation \& Newton, 2009:112). These problems are still frequently experienced by teachers and become a challenge for them in teaching speaking in the class.

In the practice of the teaching of EFL speaking in Indonesia, both English teachers and students still have been encountering many problems. Based on some research, there have been at least four main issues that some researchers and teachers often investigate. Widiati and Cahyono (2006:277) report that the teaching of EFL speaking for tertiary-level students deal with teaching problems, classroom activities, teaching materials, and assessment. These things are related to the improvement of the teaching quality of EFL speaking that would point out obvious picture of the teachers' position and what they are necessary to do.

With regard to the importance, the factors, and the problems of the speaking skill discussed above, the researcher related them to his experience in teaching listening and speaking courses. He noticed that the students of PGMI program of Hamzanwadi Islamic Institute $(I A I H) \mathrm{NW}$ at Pancor, especially those who took the English program, face many problems in their class. To know the factual problems, the researcher investigated the actual obstacles and difficulties of what the students are facing in listening and speaking courses. In this case, the researcher did a preliminary study to identify the real speaking problems that occurred in the class.

The preliminary study was conducted by having an observation, an interview and an analysis of the students' scores. The observation was done to see the teaching and learning process in the class. The researcher also had an informal interview with the teachers and he analyzed the students' achievement of their speaking performance. The result of the preliminary study showed that the students, in common, had plenty of problems in their speaking class. From the data of the students' achievement of speaking performance, it was found that the average of their speaking performance reached only 60.22 .

In the reference to the preliminary data, the researcher concluded that there were two main problems in the listening and speaking class. The first, is in terms of linguistics, the students have insufficient vocabulary needed and inaccurate pronunciation and often speak ungrammatically. While, the second, in terms of personality, the students were lack of motivation and they were reluctant to speak in the class. In addition to that, the teachers' lack of using interesting techniques with media as teaching speaking is another one. For an example, the teachers just had students read a text of dialog or conversation on the book and asked them to repeat once or twice.

Considering the problems above, the researcher intended to find out a solution of the problems being faced by the students in the class. He believed that utilizing a video as teaching media was one of the alternatives to overcome the problems of students in speaking class. It is relevant to Kelly's (1985) idea that the video has obviously given the 
contribution to language learning in many ways. In other words, the video is potentially fruitful to provide fun and interesting learning experience to encourage the student $s^{\prime}$ motivation, self confidence, and of course improve their speaking skill, in terms of their grammar, vocabulary, fluency and pronunciation. Moreover, it also would offer the students a comprehensible input of English that helped them to recognize how the target language is used, and uttered in the real context.

\section{Review of Related Literature}

\section{The Nature of Speaking}

Communication, an inevitable part of human life, has taken a very significant role in our lives. People use a language to communicate with others for expressing their willingness, intentions, ideas, and so forth. The language therefore could be a prime vehicle for the delivery of meaning. According to Ferguson (2004:37), communication is the transmission of messages among people or groups. Commonly, people communicate in spoken and written forms in their daily lives. They use these forms of communication for different purposes since they have their own characteristics or features and functions. Therefore, people might use spoken and written forms for different circumstances depending on the need and purposes. Consequently, both communications either spoken or written form becomes a pivotal part of our lives.

In language teaching, the need for spoken communication in foreign language teaching has rocketed (Mauranen, 2006:143). The main purpose of speaking is to accomplish a task such as, conveying a message, obtaining information, or expressing an opinion etc. In short, speaking for people has become an inevitable need for different situations and functions.

To speak another language, one should know how to articulate sounds in comprehensible manner, has adequate vocabulary and mastery in syntax (Nunan, 1999:226). In addition, Burns and Joyce (1999:2) argue that learning to speak occupies developing a number of complex skills and different types of knowledge about how and when we communicate. In this sense, the ability to speak another language is not that simple; it needs to know the nature and characteristic of spoken language, which requires very complex skills and knowledge of its language. Therefore, students need to gain awareness of practicing aspect of linguistics knowledge, developing production skills, and raising some socio-linguistic or pragmatic points (Hughes, 2002:6).

Speaking naturally involves an interrelation between speakers and hearers having an interaction and a communication occur properly. It means speakers and hearers are able to interact, each other, which depend on how they bring the interaction into particular conditions, and situations that, will affect to communicative events. This means speaking skill entails a communicative competence in order to produce it naturally. Flor et al. (2006:139) states that the main role of the speaking skill for communicative competence of 
the learners requires the possession of knowledge about how to produce not only linguistically correct but also pragmatically appropriate utterances. The gist of this notion is similar with Thornbury's idea discussed above that sees not only the importance of linguistics knowledge but also extralinguistics knowledge.

Similarly, speaking proficiency engages four communicative competences such as, grammatical, strategic, and sociolinguistic and discourse competence (Shumin, 2002:207). Those who want to have a proficient speaking are required to master four communicative competences in order that they can speak or do oral communication naturally.

\section{Video as Teaching Media in Teaching English}

As explained above, how important the use video in language teaching is, things teachers need to know is that they have to consider a lot on how the video can be implemented in the class. Cahyono (1997:134) describes that using video and film can provide a unique and interesting learning experience for teachers and learners, as long as they are used constructively and in varied activities in terms of leaner-centered. Cakir (2006:67) adds that the use of video offers a great help for foreign language teachers in simulating and facilitating the target language. Briefly, the video used as teaching media in English teaching has great potential to reach expected outcomes in English learning and teaching.

\section{a. Video Types}

There are some kinds of video types can be used to language teaching in the class; video taken from television, video of broadcasting news of TV news channel or video that is intentionally designed for language learning. Regard with the video types in English language teaching, Mackenzie (1997) uses the CNN news video in the EFL classroom. He concludes that news video is easy to find, manageable, timely and interesting but needs a little thought on the part of teacher as to how to support students. Amarien (1997) functions the video of television in classroom situation. She reports that video from television can be developed to stimulate learners to learn English skills. Both video types might be useful and helpful to be implemented in classroom.

However, for categories of video types used in the classroom, Harmer (2001:284) categories three basic types of video which can be readily be used in the class. First, off air programs, this kind of video type is a recorded video from a television channel by considering a sensible length, comprehensibility of the students, motivating to the students. The second type of video is real-world video. This kind of video might be taken from as feature films, exercise manuals, wild documentaries or comedy. The video also can have multi-use potential and engaging the students of course. The third is languagelearning video. This video sometimes has been designed with the students' at a particular level in mind and to appeal to the students' topic interest and multi-use and the 
comprehensible for language study. Therefore, the video types that will be presented in the classroom should be some considerations of what the classroom will be.

\section{b. Criteria for Selecting the Video}

Before using the video in the classroom, selecting the right video for a particular level of students is necessary to do. Thus, finding an appropriate feature video is one of the most useful things that a teacher can do. There are criteria to be followed in their selection (Arcario,1992; Johnston, 1999; and Stempleski, 1992, cited in Burt, 1999). He concluded some criteria that need to be taken into consideration of selecting video and the teachers asks himself the following questions before choosing a video or video series:

1) Inspiration/Motivation/Interest: Will the video appeal to my students? Will it make them want to learn?

2) Content: Does the content match my instructional goals? Is it culturally appropriate for my learners?

3) Clarity of message: Is the instructional message clear to my students?

4) Pacing: Is the rate of the language or instruction too fast for my students? Many authentic videos move at a pace difficult for a nonnative speaker to follow. Even an instructional video may be too fast paced and dense for adults new to English.

5) Graphics: What graphics are used to explain a concept? Do they clarify it? Do they appear on screen long enough to be understood by the learner?

6) Length of sequence: Is the sequence to be shown short enough? With second language learners, segments that are less than five minutes are often sufficient.

7) Independence of sequence: Can this segment be understood without lengthy explanations of the plot, setting, and character motivation preceding and following it? Teachers need to decide whether it's worth investing the time and effort to prepare learners to understand the context of certain language and cultural nuances, or distinctions.

8) Availability and quality of related materials: What print materials accompany the video? With videos designed to be used for English language instruction, the accompanying textbooks, resource books, and workbooks need to be examined carefully to see if they meet the instructional needs of the learners.

9) Use of videos: How will I use the video? In the classroom, a teacher can help students tackle video presentations that are linguistically more complex and in which the story line and characters are more ambiguous.

\section{Method}

The design of this research was Classroom Action Research (CAR). It was employed because it focused on solving the classroom problems dealing with the teaching of speaking at IAIH NW at Pancor. Lier (1990:9) points out that classroom action research is the central data deriving from things that go on in the classroom. According to Bassey 
(1998 cited in Koshy, 2005:8), an action research can be defined as an inquiry which is accomplished in order to understand, to evaluate and then to change in order to improve educational practice. Ary, et al. (2006:538) state that the goal of action research in education is to create an inquiry stance toward teaching where questioning one's own practice becomes part of the work and of the teaching culture.

This research was conducted at Hamzanwadi Institute for Islamic Studies (IAIH) NW at Pancor since the researcher is one of teachers of listening and speaking courses in this institution. The subject was the first semester students of PGMI Program of Tarbiyah Faculty of IAIH NW at Pancor in the 2017/2018 academic year as the subjects of the research. The researcher selected sixth semester students because in this semester the students of PGMI Program must have an English program for communicative purpose. This program is a compulsory course of PGMI Program of Tarbiyah Faculty of IAIH NW at Pancor in which the students are given an intensive English program for two credits in order to have a basic competence of English communication. After having the program, they are expected to have basic competence in English communication both spoken and written. In fact, their English communication competence is still far from the expected output especially their speaking performance.

In conducting this research, the researcher employed classroom action research, which aimed at solving problems that occur in the class. This classroom action research had four steps as proposed by Kemmis and McTaggart (1992 cited in Cohen, et al. 2000:229), action research develops through the self-reflective spiral: a spiral of cycles of planning, acting (implementing plans), observing (systematically), reflecting.

Setting the criteria of success in classroom action research is one of pivotal steps to judge whether the action is effective in solving the students' problems. It is also important to make sure the result of the research is successful or not. The criteria of success are designed to determine if the students' speaking skill have been improved through the use of video, then to decide whether the action would go on to next cycle or stop. This study is considered to be successful if it meets the following criteria;

a. The average of the students' speaking performance attained 75 (equal B based on IAIH NW at Pancor' scoring guideline). This means the improvement of the students' speaking skill is successful if the average score of students ' speaking performance could achieve point 75 in grade range from 10 up to 100 . It was determined on 75 (B) since the finding of the preliminary study showed that the average of the students score was only 60.22 (C) and to gain the score 75 (B) from 64 (C), the students should increase up to three levels of determined score.

b. $70 \%$ of the students have positive response. It means that $70 \%$ of the students have good or positive response to the implementation of the use of video in speaking class. It was determined $70 \%$ of the students because the preliminary 
data showed that less than $60 \%$ of the students had positive responses to the teaching and learning process particularly in speaking class.

\section{Research Finding}

The findings of this research were obtained during the implementation of the use of video in the two cycles. They encompass the result of the students' speaking performances, their attitude and their activities during the teaching and learning process. The findings of this research are related to the criteria of success, as shown in following table.

Table 01: The Description of the Criteria of Success and the Findings of the Study

\begin{tabular}{llll}
\hline No. & \multicolumn{1}{c}{ Criteria of Success } & \multicolumn{1}{c}{$\begin{array}{c}\text { Findings of the } \\
\text { Study }\end{array}$} & \multicolumn{1}{c}{ Note } \\
\hline $\begin{array}{l}\text { 1. } \\
\text { The average of the } \\
\text { students' final score was } \\
\text { IAIH Pancor' scoring } \\
\text { guideline see Appendix } \\
\text { 11) within the range of } 10\end{array}$ & $\begin{array}{l}\text { The average of the } \\
\text { students' final score } \\
\text { could reach } 85.11 \\
\text { (equal A in the range } \\
\text { of qualitative) in the } \\
\text { range of } 10 \text { to } 100\end{array}$ & $\begin{array}{l}\text { The criterion } \\
\text { was achieved. }\end{array}$ \\
$\begin{array}{l}\text { 70\% of the students had } \\
\text { positive attitude to the } \\
\text { implementation of the use } \\
\text { of video in the speaking } \\
\text { class. }\end{array}$ & $\begin{array}{l}\text { 84. 13\% of the } \\
\text { students had } \\
\text { positive attitude to } \\
\text { the implementation } \\
\text { of the use of video in } \\
\text { the speaking class }\end{array}$ & \\
\hline
\end{tabular}

\section{Findings of Cycle One}

Evaluating the finding gained from the students' speaking test in cycle one, the researcher concluded that the implementation of the use of video could improve their speaking skills. The result of data on the speaking performance (78.19) showed that it already met the first criterion of success (75) of this research. However, considering the average score of each aspect of the speaking performance in terms of grammar, vocabulary, fluency and pronunciation was still in the category "fair" or close to weak. The researcher, thus, decided to have another cycle with some revisions. The revision taken from the collaborator's observation during the cycle was importantly required to analyze the weakness of implementing process.

Dealing with the data gathered from the questionnaire, the students were requested to give personal judgment toward the implementation the use of video. It designated that the use of video in the speaking class could present the students different 
learning circumstances so that they experience meaningful activities while teaching and learning process. The result of the questionnaire showed the majority of the student or about $84.81 \%$ had positive attitude to the use of video in speaking class. It meant that this result already met the second of the criterion (70\%) of success of this research.

The relationship between the two findings, the result of speaking test and the analysis of the questionnaire is significant to decide whether or not the researcher required drawing the conclusion. The findings of cycle one revealed that there were many aspects that required to have the improvement particularly on the students' speaking skills improvement. The researcher, as a lecture, decided to have another cycle in order to see betterment.

\section{Findings of Cycle Two}

Evaluating the findings obtained from the students' speaking test in cycle two, the researcher concluded that the implementation the use of video as teaching media facilitated the students to improve their speaking skills. Based on the result of data on the speaking performance, it was found that the students statistically improved not only their speaking skills but also their attitudes toward the implementation of the use of video in teaching of speaking. Considering this finding, the researcher concluded that he did not need to conduct another cycle. The Table 02 shows the improvement of the students' speaking skills from the preliminary study to the last cycle of this research.

Table 02: The Improvement of the Students' Speaking Skills

\begin{tabular}{|l|c|c|c|}
\hline $\begin{array}{l}\text { Average Score of the } \\
\text { Students' speaking Skills }\end{array}$ & 64.81 & 78.19 & 85.11 \\
\hline The Quality Score & C & B & A \\
\hline
\end{tabular}

Dealing with the data collected from the questionnaire, it revealed that more than $84.13 \%$ of the students had positive attitude to the implementation the use of video as teaching media in teaching speaking. In general, the use of video presented the students different learning experiences so that they had meaningful activities in learning process. It meant that this result already met the second of the criteria of success of this research.

Based on the two findings from the result of speaking test and the analysis of the questionnaire, it showed the significant improvement of the students' speaking skills and positive responses to the use of video as teaching media in teaching speaking. Both the speaking performance and the questionnaire data reveals that the students' speaking performance and attitude toward the implementation the use of video were positive as they were involved in speaking class. With regard to the findings, the researcher concluded that he did not need to conduct another cycle.

To conclude the findings, the researcher obviously pointed up that the use of video as teaching media in speaking class was a valuable means to improve not only the 
students' speaking skills but also their positive attitude to learn English particularly in learning speaking.

\section{Conclusion}

In light of the findings and the discussions of the research in the preceding chapter, the researcher draws a conclusion that the use of video as teaching media has been proven to be able to improve the speaking skill of the first semester students of PGMI Program of Tarbiyah Faculty of Hamzanwadi Institute for Islamic Studies (IAIH) NW at Pancor. This conclusion is derived from the result of analyzing on the students' speaking performance and their attitude toward the implementation activities.

Related to the students' improvement in speaking performance after cycle two, it is concluded that the implementation of the use of video as a teaching media in speaking class can improve the students' speaking skill. Besides it can improve the students' speaking skill, the researcher also found that the students had positive attitude to the implementation of video in speaking class.

In short, this research has revealed that the use of video can be an alternative to solve the students' problems in speaking English and it should be considerably used in the speaking class not only for the reason that it can improve the students' speaking skills but also because it can promote the students' positive attitudes towards language learning.

The implementation of the use of video as teaching media in speaking class can cover some procedures into three main phases: The first phase is pre-viewing, (1) eliciting the target vocabulary to be used in the video and writing them down on the board, (2) elaborating the target vocabulary with the target expressions used of the video, (3) telling the students on what they are going to study about and setting up the classroom so that they will be ready to watch video. The second phase is whilst-viewing (1) assigning the students to watch the video (without the sound) and asking the students to predict things (place, actions, expressions), (2) playing the video (with the sound) and letting students check their own prediction, (3) giving students three chances to watch the video with sound, (4) having students do rehearsal focusing on vocabulary, pronunciation and expressions used in the video. The third phase is post-viewing, (1) providing another sheet of dialog/conversation text and asking the students to identify typical expressions relevant to the topic, (2) assigning the students to act out or doing role play with similar topic of the video in pairs or group, (3) giving the feedback and corrections from the students performances.

\section{REFERENCES}

Amarien, C. 1997. The use of Television in Language Leaning. English Language Education, 3(1), 37-42. 
Ary, D., Jacobs., L.C., Razavieh, A. \& Sorensen, C. 2006. Introduction to Research in Education. Belmont: Thomson.

Broady, E. 2005. The four language skills or 'juggling simultaneous constraints' In James A, C \& John, K (Eds.), Effective Learning and Teaching in Modern Languages. Oxon: Roultledge.

Brown, H. D. 2001. Teaching by Principle: An Interactive Approach to Language Pedagogy. New York: Longman.

Burt, M. 1999. Using Video with Adult English Language Learners. (www.cal.org/caela/esl_resources/digests/using video with Adult leaner.html accessed on April, $1^{\text {st } 2009)}$

Burns, A., \& Joyce, H. 1997. Focus on Speaking. Sydney: Macquarie University Press.

Cahyono, B. Y. 1997. Pengajaran Bahasa Inggris: Teknik, Strategi, dan Hasil Penelitian. Malang: IKIP Malang.

Çakir, İ. 2006. The Use of Video as an Audio-Visual Material in Foreign Language Teaching Classroom. The Turkish Online Journal of Educational Technology -TOJET, 5 (4):67-72.

Cohen, L., Manion. L., \& Morrison, K. 2000. Research Methods in Education. London: RoutledgeFalmer.

Davis, R. 1998. Captioned Video: Making it Work for You. The Internet TESL Journal,(4)3 (http://iteslj.org/ accessed on March 3rd 2009)

Ferguson. 2004. Communication Skill. New York: Ferguson.

Flor, A., Juan, E. \& Soler. E. 2006. Towards Acquiring Communicative Competence through Speaking. In. E. U. Juan, \& A. M. Flor (Eds.), Current Trends in the Development and Teaching of the Four Language Skills. Berlin: Mouton de Gruyter.

Graham, S. 2007. Developing Speaking Skills in the Modern Foreign Language. In. Norbert, P. \& Ana, R. (Eds.), A Practical Guide to Teaching Modern Foreign Languages in the Secondary School. Oxon: Roultledge

Harmer, J. 2001. The Practice of English Language Teaching. Essex: Pearson Education.

Hughes, R. 2002. Teaching and Researching Speaking. London: Pearson Education.

Kelly, R. 1985. Video and Language Learning: An Approach to Viewing Comprehension. Teodoro, A. (ed.), RELC Journal, 10(1), 52-67.

Koshy, V. 2005. Action Research for Improving Practice. London: Paul Chapman.

Mauranen, A. 2006. Spoken Discourse, Academics and Global English: a Corpus Perspective In. R. Hughes.(Ed.), Spoken English, TESOL and Applied Linguistics Challenges for Theory and Practice. New York: Palgrave Macmillan.

Nation, I. \& Newton, J. 2009. Teaching ESL/EFL Listening and Speaking. New York: Routledge.

Nunan, D. 1999. Second Language Teaching and Learning. Hongkong: Heinle and Heinle. 
Rarastesa, Z. 2004. Introducing Culture in ELT Classroom: Experience in the Teaching of Pronunciation and Speaking. In. B.Y. Cahyono \& W. Utami (Eds.), The Tapestry of English Language Teaching and Learning in Indonesia (pp.317-325). Malang: State University of Malang Press.

Richards, J. C., \& Renandya, W. A. (Eds.) 2002. Methodology in Language Learning. Cambridge: Cambridge University Press.

Shumin, K. 2002. Factors to Consider: Developing Adult EFL Students' Speaking Abilities. In. J. C. Richard, \& W. A. Renandya (Eds.), Methodology in Language Teaching an Anthology of Current Practice (pp.204-211). Cambridge: Cambridge University Press.

Stempleski, S. 2002. Video in the ELT Classroom: The Role of the Teacher. In J. C. Richards, \& W. A. Renandya (Eds.), Methodology in Language Teaching An Anthology of Current Practice (pp.364-367). Cambridge: Cambridge University Press.

Stempleski, S. \& Tomalin, B. 1990. Video in Action: Recipes for Using Video in Language Teaching. New York: Prentice Hall.

Thornbury, S. 2005. How to Teach Speaking. Essex: Pearson Education.

Ur, P. 1996. A Course in Language Teaching. Cambridge: Cambridge University Press.

Widiati, U \& Cahyono. B. 2006. The Teaching of EFL Speaking in The Indonesian Context: The State of The Art. Jurnal BAHASA DAN SENI, (34) 2, 269-291.

Willis, D. 1983. The potential and limitation of video. In. J. McGovern. (Ed.), Video Application in English Language Teaching. Oxford : Pergamon.

Willis, J. 1983. The Role of The visual Element in Spoken Discourse: Implication for the Exploitation of Video in EFL Classroom. In. J. McGovern. (Ed.), Video Application in English Language Teaching. Oxford : Pergamon. 